\title{
A MILK-SPREAD EPIDEMIC OF SCARLET FEVER
}

\author{
By R. DOUGLAS \\ Medical Officer of Health, Moray and Nairn County \\ J. SMITH \\ Regional Bacteriologist, Aberdeen \\ I. N. SUTHERLAND \\ Medical Officer, Department of Health for Scotland \\ AND R. J. P. WATSON \\ Divisional Veterinary Officer, Ministry of Agriculture
}

THE following account of a milk-spread epidemic of scarlet fever in the burgh of Elgin may be of interest to those who are at times faced with similar problems.

\section{HISTORY}

The number of cases of scarlet fever notified in the burgh each year from 1920 to 1938 is given in Table 1 . This table also shows that the periods of

Table 1. Scarlet fever notifications, 1920-38

$\begin{array}{ccc}\text { Year } & \text { Elgin burgh } & \text { Whole area* } \\ 1920 & 11 & 83 \\ 1921 & 43 & 162 \\ 1922 & 13 & 75 \\ 1923 & 7 & 87 \\ 1924 & 2 & 59 \\ 1925 & 32 & 74 \\ 1926 & 44 & 140 \\ 1927 & 7 & 205 \\ 1928 & 2 & 117 \\ 1929 & 3 & 19 \\ 1930 & 3 & 54 \\ 1931 & 4 & 49 \\ 1932 & 18 & 77 \\ 1933 & 35 & 463 \\ 1934 & 66 & 454 \\ 1935 & 69 & 363 \\ 1936 & 34 & 155 \\ 1937 & 19 & 59 \\ 1938 & 11 & 2837 \\ \text { Totals } & 423 & \end{array}$

maximal incidence, centring on 1921, 1926 and 1934, are related roughly to the periods of maximal incidence of all cases in the area, which area includes the counties of Moray and Nairn and the burghs situated within the counties. A prolonged epidemic occurred in the whole area from 1933 to 1935, the age distribution of cases at different stages of that epidemic (Douglas, 1935) being 
given in Table 2. It is regretted that present circumstances do not permit of a more detailed analysis of the age and sex distributions of this epidemic. There was no evidence that the disease was spread by milk.

Table 2. Age incidence of scarlet fever in the whole area during the 1933-5 epidemic

$\begin{array}{lrlccccc}\quad \text { Period } & 0-4 & 5-14 & 15-24 & 25-44 & 45-64 & 65+ & \text { All ages } \\ \text { 1. viii. 33-31. xii. 33 } & 42 & 213 & 26 & 27 & 7 & - & 315 \\ \text { 1. i. 34-31. xii. 34 } & 105 & 259 & 37 & 44 & 9 & - & 454 \\ \text { 1. i. 35-31. vii. 35 } & 37 & 145 & 21 & 14 & 5 & - & 222 \\ \quad \text { Totals } & 184 & 617 & 84 & 85 & 21 & - & 991\end{array}$

During the inter-epidemic years $1936-8$, the number of cases notified in Elgin and district was 82 . The age and sex distributions of these cases are given in Table 3. No evidence suggesting that any of these cases were infected by milk was found.

Table 3. Age and sex distributions of scarlet-fever cases in Elgin and district during 1936, 1937 and 1938

\begin{tabular}{|c|c|c|c|c|c|c|c|c|c|c|}
\hline \multirow[b]{2}{*}{ Ages } & \multicolumn{2}{|r|}{1936} & \multicolumn{2}{|r|}{1937} & \multicolumn{3}{|c|}{1938} & \multicolumn{3}{|c|}{$1936-8$} \\
\hline & M. & F. Total & M. & F. Total & M. & F. & Total & M. & F. & Total \\
\hline $0-4$ & 4 & 610 & 3 & 一 & 3 & 1 & 4 & 10 & 7 & 17 \\
\hline $5-9$ & 4 & $12 \quad 16$ & 2 & $8 \quad 10$ & 1 & i & 2 & 7 & 21 & 28 \\
\hline $10-14$ & 1 & 4 & 3 & 7 & - & 5 & 5 & 4 & 13 & 17 \\
\hline $15-19$ & - & 4 & - & 2 & - & 2 & 2 & - & 8 & 8 \\
\hline $20-24$ & - & 3 & 1 & 2 & 1 & - & 1 & 2 & 5 & 7 \\
\hline 25-29 & 一 & 2 & - & - & - & 1 & 1 & - & 3 & 3 \\
\hline $30-34$ & - & $-\quad-$ & - & - & - & - & - & $\dot{-}$ & - & - \\
\hline 35-39 & - & 1 & + & - & - & - & - & - & 1 & 1 \\
\hline $40-44$ & - & - - & - & - & - & - & - & 一 & - & - \\
\hline $45-49$ & - & -- & - & - & 一 & 一 & 一 & - & - & - \\
\hline $50-54$ & 一 & - & - & - & - & 一 & - & - & - & - \\
\hline 55-59 & - & - & - & - & - & - & 一 & 一 & - & - \\
\hline $60-64$ & - & -- & 一 & - & 1 & 一 & 1 & 1 & - & 1 \\
\hline 65- & 一 & -- & - & - & - & - & - & - & - & - \\
\hline Totals & 9 & 3241 & 9 & $16 \quad 25$ & 6 & 10 & 16 & 24 & 58 & 82 \\
\hline
\end{tabular}

The 1939 epidemic

Notifications of scarlet fever arrived in increasing numbers during the third and fourth weeks of January 1939. A table showing the numbers of notifications received each day is not given, but Table 4 records the cases by their dates of onset, together with their sex and milk supplies. The peak day of onset was 26. i. 39. After the case which arose on 2. iii. 39 there was an interval of a week before the onset of the next case, and the date 2. iii. 39 has been taken as terminating this epidemic.

Investigations made in the home of each patient by the epidemic officers of the sanitary staff showed that one factor only was frequently associated with the disease, the consumption of milk from a supply which will be designated A. In all, the patients received milk from twenty sources, and the distribution of these supplies to the infected persons is given in Table 5 . 
Milk supply $A$. This supply was drawn from cows in a registered herd at one farm. The cows were kept under excellent conditions. They were milked mechanically, with all the precautions usually observed in a first-class dairy

Table 4. 1939 epidemic: cases by milk supply, date of onset and sex

\begin{tabular}{|c|c|c|c|c|c|c|c|c|c|c|c|c|c|}
\hline \multirow{2}{*}{$\begin{array}{l}\text { Date of } \\
\text { onset }\end{array}$} & \multicolumn{3}{|c|}{ Supply A only } & \multicolumn{4}{|c|}{ Supply A plus others } & \multicolumn{3}{|c|}{ Other supplies only } & \multicolumn{3}{|c|}{ Totals } \\
\hline & M. & F. & Total & M. & F. & Total & & M. & F. & Total & M. & F. & Tota \\
\hline 13. i & 一 & 1 & 1 & 一 & - & 一 & & - & - & 一 & - & 1 & 1 \\
\hline 14. i & 一 & - & 一 & 1 & - & 1 & & 一 & 一 & 一 & 1 & - & 1 \\
\hline 15. i & - & - & - & - & - & - & & - & - & - & - & - & - \\
\hline 16. i & 1 & - & 1 & 1 & - & 1 & & - & - & - & 2 & - & 2 \\
\hline 17. $\mathrm{i}$ & - & 1 & 1 & 一 & - & 一 & & - & 一 & - & - & 1 & 1 \\
\hline 18. i & 3 & - & 3 & - & 一 & - & & 1 & - & 1 & 4 & - & 4 \\
\hline 19. i & 2 & 2 & 4 & 1 & 1 & 2 & & 一 & 1 & 1 & 3 & 4 & 7 \\
\hline 20. i & 2 & 1 & 3 & 2 & 1 & 3 & & 一 & 一 & 一 & 4 & 2 & 6 \\
\hline 21. i & 1 & 1 & 2 & 1 & 5 & 6 & & - & - & - & 2 & 6 & 8 \\
\hline $22 . \mathrm{i}$ & - & 4 & 4 & 3 & 一 & 3 & & $\leftarrow$ & - & 一 & 3 & 4 & 7 \\
\hline 23. i & 4 & 3 & 7 & 2 & 2 & 4 & & - & - & - & 6 & 5 & 11 \\
\hline $24 . i$ & 3 & 8 & 11 & 3 & - & 3 & & - & 1 & 1 & 6 & 9 & 15 \\
\hline 25. i & 6 & 14 & 20 & 4 & 3 & 7 & & 一 & - & - & 10 & 17 & 27 \\
\hline 26. i & 12 & 4 & 16 & 9 & 5 & 14 & & - & 1 & 1 & 21 & 10 & 31 \\
\hline 27. i & 5 & 6 & 11 & 6 & 4 & 10 & & - & 1 & 1 & 11 & 11 & 22 \\
\hline 28. i & 2 & 4 & 6 & 4 & 3 & 7 & & - & 2 & 2 & 6 & 9 & 15 \\
\hline $29 . \mathrm{i}$ & 3 & 3 & 6 & 1 & 2 & 3 & & 1 & - & 1 & 5 & 5 & 10 \\
\hline 30. i & 3 & - & 3 & 1 & 1 & 2 & & - & - & - & 4 & 1 & 5 \\
\hline 31. i & 3 & 1 & 4 & 一 & - & 一 & & 1 & - & 1 & 4 & 1 & 5 \\
\hline 1. ii & 一 & - & - & 一 & - & - & & - & 一 & 一 & - & - & - \\
\hline 2. ii & - & 2 & 2 & - & 一 & - & & 1 & - & 1 & I & 2 & 3 \\
\hline 3. ii & - & - & 一 & 一 & - & - & & - & 一 & - & - & - & - \\
\hline 4. ii & - & 1 & 1 & 一 & - & - & & 1 & 2 & 3 & 1 & 3 & 4 \\
\hline 5. ii & 一 & - & - & 1 & - & 1 & & - & 1 & 1 & 1 & 1 & 2 \\
\hline 6. ii & - & - & - & - & - & - & & 1 & - & 1 & 1 & - & 1 \\
\hline 7. $\ddot{i}$ & - & - & - & - & 1 & 1 & & - & 1 & 1 & - & 2 & 2 \\
\hline 8. ii & 1 & - & 1 & 1 & - & 1 & & 2 & - & 2 & 4 & - & 4 \\
\hline 9. ii & - & 1 & I & - & - & - & & 1 & - & 1 & 1 & 1 & 2 \\
\hline 10. ii & - & 1 & 1 & 1 & 1 & 2 & & 一 & 一 & - & 1 & 2 & 3 \\
\hline 11. ii & - & - & - & 一 & - & 一 & & - & - & - & - & - & - \\
\hline 12. ii & 1 & 一 & 1 & - & - & 一 & & - & - & - & 1 & - & 1 \\
\hline 13. ii & - & 1 & 1 & - & - & - & $\cdot$ & - & 一 & - & - & 1 & 1 \\
\hline 14. ii & - & 1 & 1 & 一 & - & - & & - & - & - & - & 1 & 1 \\
\hline 15. ii & - & - & - & - & - & - & & - & - & - & - & - & 一 \\
\hline 16. ii & - & - & - & - & - & - & & - & - & - & - & - & - \\
\hline 17. ii & - & - & - & 一 & - & - & & - & 一 & - & - & - & - \\
\hline 18. ii & 一 & - & 一 & - & 1 & 1 & & 一 & 1 & 1 & - & 2 & 2 \\
\hline 19. ii & - & 1 & 1 & - & - & - & & - & - & - & - & 1 & 1 \\
\hline 20. ii & - & - & - & - & - & - & & - & 1 & 1 & - & 1 & 1 \\
\hline 21. ii & - & - & - & - & - & - & & - & - & - & - & - & - \\
\hline 22. ii & - & - & - & - & - & - & . & - & - & - & - & 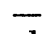 & - \\
\hline 23. ii & - & - & - & - & 1 & 1 & & - & - & - & - & 1 & 1 \\
\hline 24. ii & - & 一 & - & - & - & - & & - & - & - & - & - & - \\
\hline 25. ii & - & 1 & 1 & - & 一 & - & & - & 1 & 1 & - & 2 & 2 \\
\hline 26. ii & - & - & - & - & - & - & & 1 & - & 1 & 1 & - & 1 \\
\hline 27. ii & - & - & - & 1 & - & 1 & & - & - & - & 1 & - & 1 \\
\hline 28. ii & - & - & - & - & 一 & - & & 1 & - & 1 & 1 & - & 1 \\
\hline 1. iii & 一 & - & - & 一 & 一 & - & & 1 & 一 & 1 & 1 & - & 1 \\
\hline 2. iii & 一 & 1 & 1 & 一 & 一 & - & & - & - & - & - & 1 & 1 \\
\hline Totals & 52 & 63 & 115 & 43 & 31 & 74 & & 12 & 13 & 25 & 107 & 107 & 214 \\
\hline
\end{tabular}

farm, and the udders were 'stripped' by hand. The milk was bottled at the farm. All milk bottles were washed, filled and capped by machinery. The herd and the milking arrangements were under the management of one family, with the help of a man who lived apart from the family. 
On leaving the farm, all the milk was sent to an associated distribution depot, from which milk could be bought retail and from which milk was regularly delivered by five roundsmen.

Geographical distribution. It was noticed, in the early stages of the epidemic, that the incidence was higher in the delivery area of one of these roundsmen than in the rest of the burgh. He was delivering milk in capped bottles only, and it was difficult to see how, even if he were infecting the milk, the organism could gain access to it. Swabbing of all the roundsmen showed that none of them harboured haemolytic streptococci in the throat and that none of them suffered from otorrhoea or any other condition which might possibly have led

Table 5. 1939 epidemic: milk supplies

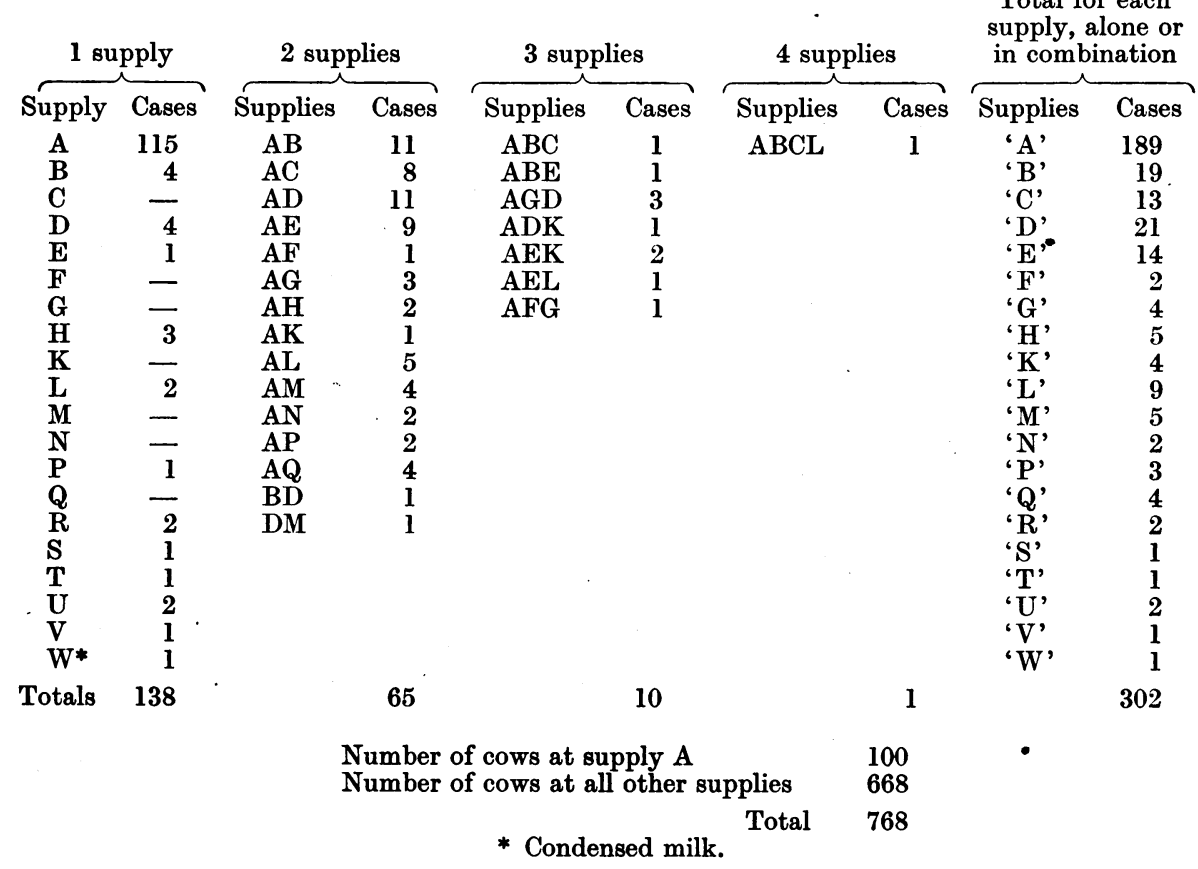

to the discharge from the body of haemolytic streptococci. The selective geographical incidence of the infection did not continue beyond the earlier stages of the epidemic, and a final spot map shows so little that it is not reproduced herein.

Investigation at the farm. The farm was visited on 27. i. 39, and many times thereafter. These visits yielded the following information about the family, which managed the herd and the milking arrangements:

25. xii. 38-1. i. 39. A.Z. (female, aged 15), who was in contact with cows, milk and milk bottles, was ill with general malaise and headache. She was seen on 28. i. 39, and found to be desquamating slightly. By 31. i. 39 she was desquamating freely. 
1. i. 39-10. i. 39. B.Z. (female, aged 11) was vaguely ill and was away from school for a day or two.

10. i. 39-16. i. 39. C.Z. (male, aged 9) was vaguely ill and was away from school during this period. When seen by one of the public health medical staff on 27. i. 39 he was found to be desquamating and to have cervical adenitis.

28. i. 39. D.Z. (male, aged 18), who did not work in the dairy farm, was seen at home in the early stages of scarlet fever.

These four persons were isolated in hospital on 28. i. 39, and the other members of the family were kept away from the dairy farm until all were found to be free by bacteriological evidence from the infection. The man who assisted the family was similarly excluded, and was found to be bacteriologically negative.

Investigation of possible bovine infection. On 31. i. 39, of 100 cows in the herd, sixty-eight were in milk. Among the thirty-two cows which were not supplying milk for human consumption there were three which had been excluded in December 1938 because of mastitis.

All the cows were examined clinically just after the morning milking on 31. i. 39. Of the sixty-eight cows in milk, one had an enlarged supramammary gland; the others showed no clinical signs of disease. The sixty-seven apparently normal cows were divided into groups of about eight, and group specimens of the milk were taken in sterile specimen bottles. Separate specimens were taken from the cow with the enlarged supramammary gland, and from the three cows which had been excluded from the herd in December 1938. Bacteriological examination showed that the four individual specimens did not contain haemolytic streptococci, but that one of the group specimens taken from clinically healthy animals contained them.

The infective cow. The positive group of cows was excluded on 2. ii. 39 and the milk of each cow tested separately. One cow only gave haemolytic streptococci. On repetition these tests gave the same results. The streptococci belonged to Lancefield's Group A, Griffith's Type 3. Closer examination revealed that the streptococci were being excreted by only one quarter of the udder. The cow was kept under observation for a considerable time. For the first three weeks it remained apparently normal on clinical examination, but at the end of this period the one quarter of the udder from which haemolytic streptococci had been consistently recovered became indurated.

It was found on investigation at the farm that the milk from all the cows was not usually pooled. The milk from the infected cow was usually distributed, mixed with the milk from a number of other cows, in the area of the roundsman where the initial incidence had been unusually high.

Bacteriology of human cases. It was impossible to perform a detailed bacteriological examination of every patient, but ten throat swabs were taken at random from patients. Every swab examined yielded haemolytic streptococci of Lancefield's Group A, Griffith's Type 3. 
Clinical type of the disease. Those persons who developed scarlet fever showed typical signs and symptoms of an attack; the disease was mainly mild or of moderate severity. There was no death directly attributable to scarlet fever. It was reported that many persons who did not develop scarlet fever had sore throats during the epidemic; but no estimate can be given of their numbers, except that they were large. The proportion of patients who developed local infective complications was not unusually high, and there was no history of the development of nephritis. In the later stages of the epidemic, an unusually large number of notifications of erysipelas was received. This disease was not a complication, for it occurred in persons who did not have scarlet fever.

Table 6. 1939 epidemic: cases by age groups, sex and milk supply

\begin{tabular}{|c|c|c|c|c|c|c|c|c|c|c|c|c|}
\hline \multirow{2}{*}{$\begin{array}{l}\text { Age group } \\
\text { (inclusive) }\end{array}$} & \multicolumn{3}{|c|}{ Supply A only } & \multicolumn{3}{|c|}{ Supply A plus others } & \multicolumn{3}{|c|}{ Other supplies only } & \multicolumn{3}{|c|}{ Totals } \\
\hline & M. & F. : & Total & M. & F. & Total & M. & F. & Total & M. & F. & Total \\
\hline $\begin{array}{c}0-4 \\
5-9 \\
10-14 \\
15-19\end{array}$ & $\begin{array}{r}12 \\
7 \\
4 \\
5\end{array}$ & $\begin{array}{r}11 \\
13 \\
8 \\
2\end{array}$ & $\begin{array}{r}23 \\
20 \\
12 \\
7\end{array}$ & $\begin{array}{r}8 \\
8 \\
4 \\
11\end{array}$ & $\begin{array}{l}4 \\
4 \\
8 \\
5\end{array}$ & $\begin{array}{l}12 \\
12 \\
12 \\
16\end{array}$ & $\begin{array}{l}1 \\
3 \\
1 \\
3\end{array}$ & $\begin{array}{l}4 \\
2 \\
4 \\
1\end{array}$ & $\begin{array}{l}5 \\
5 \\
5 \\
4\end{array}$ & $\begin{array}{r}21 \\
18 \\
9 \\
19\end{array}$ & $\begin{array}{r}19 \\
19 \\
20 \\
8\end{array}$ & $\begin{array}{l}40 \\
37 \\
29 \\
27\end{array}$ \\
\hline $\begin{array}{l}20-24 \\
25-29 \\
30-34 \\
35-39\end{array}$ & $\begin{array}{r}4 \\
1 \\
10 \\
2\end{array}$ & $\begin{array}{l}6 \\
6 \\
6 \\
1\end{array}$ & $\begin{array}{r}10 \\
7 \\
16 \\
3\end{array}$ & 1 & $\begin{array}{l}1 \\
2 \\
2 \\
1\end{array}$ & $\begin{array}{l}2 \\
3 \\
5 \\
2\end{array}$ & $\frac{2}{=}$ & $\overline{2}$ & $\frac{2}{2}$ & $\begin{array}{r}7 \\
2 \\
2 \\
13 \\
3\end{array}$ & $\begin{array}{r}7 \\
8 \\
10 \\
2\end{array}$ & $\begin{array}{r}14 \\
10 \\
23 \\
5\end{array}$ \\
\hline $\begin{array}{l}40-44 \\
45-49 \\
50-54 \\
55-59\end{array}$ & $\begin{array}{l}2 \\
1 \\
1 \\
1\end{array}$ & $\begin{array}{r}3 \\
3 \\
1\end{array}$ & $\begin{array}{l}5 \\
4 \\
1 \\
2\end{array}$ & $\begin{array}{l}1 \\
2 \\
1 \\
-\end{array}$ & $\begin{array}{l}2 \\
1 \\
\end{array}$ & $\begin{array}{r}3 \\
3 \\
1 \\
-\end{array}$ & $\bar{z}$ & $\bar{z}$ & E & $\begin{array}{l}3 \\
3 \\
2 \\
1\end{array}$ & $\begin{array}{r}5 \\
4 \\
1\end{array}$ & $\begin{array}{l}8 \\
7 \\
2 \\
2\end{array}$ \\
\hline $\begin{array}{l}60-64 \\
65-69\end{array}$ & $\stackrel{2}{-}$ & $\overline{2}$ & $\begin{array}{l}2 \\
2\end{array}$ & $\overline{2}$ & 1 & $\begin{array}{l}1 \\
2\end{array}$ & $\underline{2}$ & 二 & 2 & $\begin{array}{l}4 \\
2\end{array}$ & $\begin{array}{l}1 \\
2\end{array}$ & $\begin{array}{l}5 \\
4\end{array}$ \\
\hline & - & - & - & - & - & - & - & - & - & - & - & - \\
\hline 75-79 & 一 & 1 & 1 & - & - & - & - & - & - & - & 1 & 1 \\
\hline Totals & 52 & 63 & 115 & 43 & 31 & 74 & 12 & 13 & 25 & 107 & 107 & 214 \\
\hline
\end{tabular}

Table 7. 1939 epidemic: houses with 1, 2, 3 and 4 cases, classified by milk supply

Supply A

Supply A plus others Other supplies only

Totals

$\begin{array}{cccccc}1 \text { case } & 2 \text { cases } & 3 \text { cases } & 4 \text { cases } & \begin{array}{c}\text { Total } \\ \text { houses }\end{array} & \begin{array}{c}\text { Total } \\ \text { cases }\end{array} \\ 64 & 16 & 5 & 1 & 86 & 115 \\ 44 & 10 & 2 & 1 & 57 & 74 \\ 21 & 2 & - & - & 23 & 25 \\ 129 & 28 & 7 & 2 & 166 & 214\end{array}$

Age and sex distributions. These are given in Table 6, which also shows the milk supply for the various groups.

Detailed tables of social distribution have been made out on the available information, which included the type of house, number of rooms in the house, number of inmates over and under fourteen years of age in the house, number of each group of inmates who had not had scarlet fever, milk supplies, lighting, ventilation, water supplies, sanitation and drainage, but have not been reproduced herein, as they do rot seem to.show any characteristic features in this epidemic. In Table 7, however, the milk supplies, and the number of houses with one, two, three and four cases are shown. 
Measures taken to limit the spread of the epidemic. Scarlet fever occurred in children attending eight schools, of which three had 17, 15 and 15 cases out of 70 affected school children. Two schools were closed in the early stages of the epidemic. Isolation of scarlet-fever patients was effected either in the County Fever Hospital or at home; and contacts were quarantined or allowed their freedom according to local circumstances. In the morning of 1 . ii. 39, the following leaflet was distributed partly through the schools and partly from door to door:

'In view of the widespread outbreak of scarlet fever in Elgin and district, it is strongly advised that all milk intended for human use should meantime be boiled.'

The instruction given in this pamphlet (by R. D.) was undoubtedly obeyed by the recipients. The measures taken at the dairy farm have been described already.

\section{Discussion}

We have concluded that this epidemic was one spread by an infected cow, but the means by which the cow became infected has not been definitely established. A.Z., whose relevant medical history has been already given, sometimes helped in the stripping operation after mechanical milking. B.Z. and C.Z. sometimes visited the cowsheds, but were too young to take any active part in the work. D.Z. was not in contact with the cows. The date of onset of the first case in this epidemic is taken as 13. i. 39, which may be compatible with a bovine infection contracted from A.Z. who was ill between 25. xii. 38 and 1. i. 39 , and was peeling freely on 31. i. 39.

There is evidence of some difference of opinion about the characteristics of a milk-borne epidemic. Thus, Scott (1934) makes the following statement: 'Outbreaks... of an explosive nature, involving children more than adults, females more than males, and of the males a greater incidence below the age of fifteen years - points in favour of what we have come to recognize as characters of a milk-borne infection.' Picken (1936), on the other hand, after a résumé of American, English and Scottish views, says: 'It has therefore surprised me to find that students in England are still taught that children and women are chiefly involved in outbreaks of milk-borne infection.' It may be of interest to refer to the comparison of water-borne and milk-borne outbreaks of enteric fever made by Hill \& Mitra (1936) which led them to the conclusion that the age and sex proportions of those attacked in such epidemics, though differing somewhat on the average, would be very slender evidence of the probable medium of infection in a particular instance. Reverting to scarlet fever, the opinion of Scott, quoted above, has been held to apply to epidemics in England, whereas the experience in America and Scotland has led to directly opposite conclusions. Comparison of Tables 2, 3 and 6 shows, for the times and places under review, that during the epidemic and inter-epidemic periods, when infection was not milk-borne, children and females were chiefly involved; but that this involvement is not a feature of the milk-borne epidemic of 1939. 
In Table 8 we have compared the age distributions of this epidemic, and the Chelmsford milk-spread epidemic (Sleigh, 1936) with the age distributions found in Elgin for non-milk-spread scarlet fever in epidemic and inter-epidemic periods; and with, for further comparison, figures for 1937 extracted from the Annual Report of the Department of Health for Scotland (1938, p. 197). It may be assumed that the Scottish figures, though perhaps including a number of milk-spread cases, are on the whole representative of non-milk-spread infection.

It will be noted that our tabulations of the cases of the 1939 epidemic are usually subdivided according to the milk supplies. We have concluded that those patients who received milk from supply A only should be regarded as primary cases, though this introduces the difficulty that the patient whose date of onset was 2 . iii. 39, twenty-eight days after the exclusion of the infected cow from the herd, is included as a primary case. In the second group of patients, who received milk from supply $A$ and one or more other supplies, the probability that they were infected by supply $A$ is so high that we regard them also as primary cases, though we have tabulated them separately. If some of them are wrongly included as primary cases, the only result will be that the characteristics of the group of true primary cases will thereby be made slightly less salient. We regard the group of twenty-five patients who did not receive milk from supply $A$ as non-primary cases. The comparative age and sex distributions of primary and non-primary cases may therefore be taken from Table 6 .

It has been mentioned that the tables of social distribution had not been reproduced for what are considered good reasons. The social incidence does not appear to have been selective, perhaps in part because supply $\mathbf{A}$ did not supply milk to any of the large institutions in the neighbourhood. Two cases occurred in a general hospital; both were in the category of 'secondary' cases.

Table 7 shows a point which may be worthy of investigation in other epidemics. It will be seen that, when those patients who received infected milk (supply A only) are arranged in groups according to whether there were $1,2,3,4, \ldots$ cases in a house, the number of houses in each category makes an almost perfect geometrical progression, with a ratio of $1 / 4$ between successive terms. A very similar progression is found in those houses in which patients received their milk from 'Supply A plus others'; but the ratio is upset in the line which shows those houses ('Others only') where the patients did not receive any milk from supply $A$. It would diverge even more if the two. patients who contracted scarlet fever in the general hospital had been shown as two cases in separate houses; actually in the table they are shown as two cases in one house. It will be recalled that the patients summarized in lines 1 and 2 of this table are treated by us as primary cases, and that line 3 represents those whom we regard as secondary cases.

It is not and cannot be claimed that the measures taken in dealing with this epidemic succeeded in 'stamping it out'. The peak day of onset was 


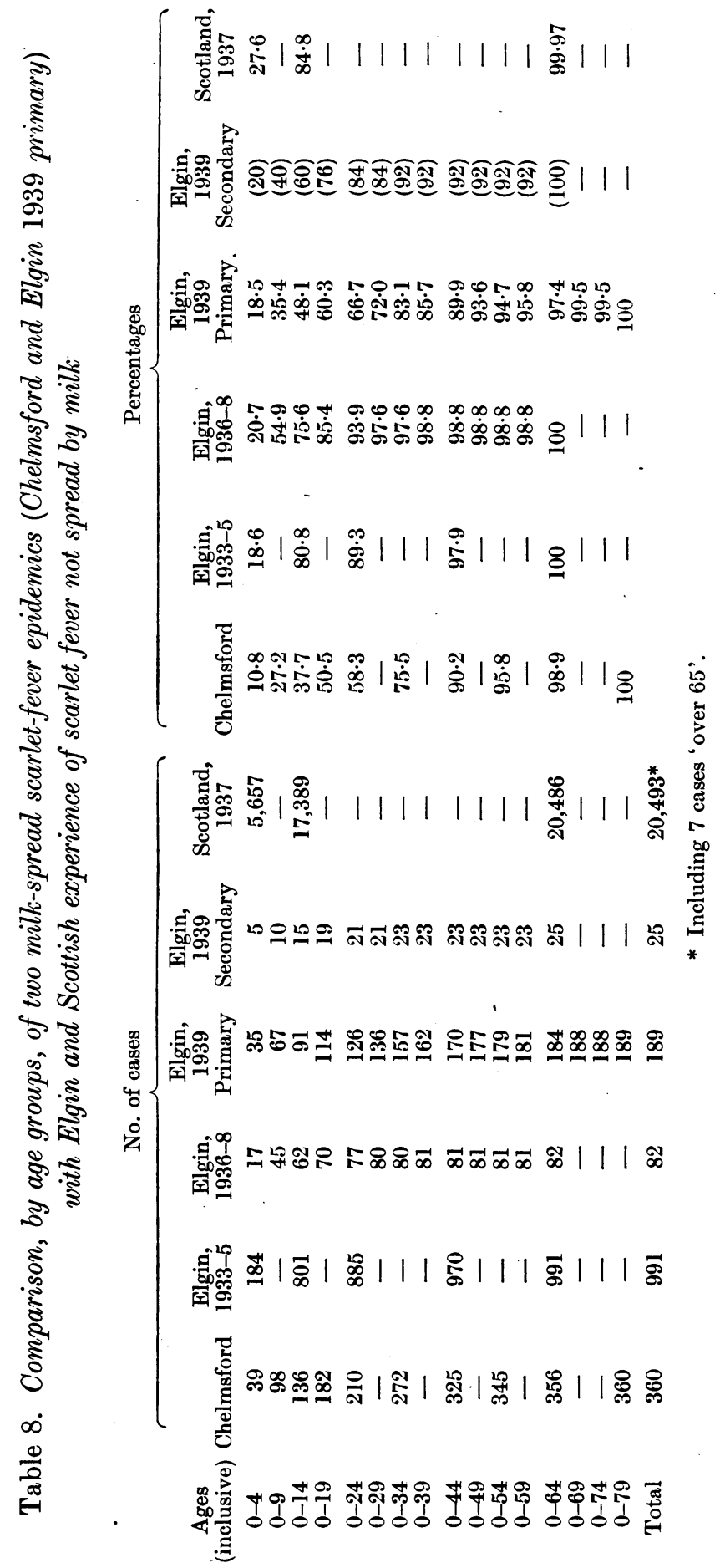


26. i. 39, seven days before the infected cow was excluded from the herd. Admittedly, even on the day when the cow was excluded notifications of scarlet fever were being received in exceptional numbers, and it was not then known whether the tendency was to be towards an increasing, stationary or decreasing incidence. The infective cow had to be excluded, and it is not worth while considering what might have happened if exclusion had not been carried out. We think it may be claimed, however, that the 1939 epidemic shows clearly the characteristics of an undoubtedly milk-borne epidemic in this time and place, and that these may be contrasted with the characteristics of nonmilk-borne cases in epidemic and inter-epidemic periods.

\section{SUMmaRY}

1. An account is given of an epidemic of 214 cases of scarlet fever occurring in Elgin between 13. i. 39 and 2. iii. 39.

2. A random sample of the patients showed that the causative organism was a haemolytic streptococcus giving the reactions of Lancefield's Group A and Griffith's Type 3.

3. The probability that the infection was spread in the milk from one supply was high.

4. Evidence is given which points to the occurrence of frank and subclinical cases of scarlet fever in members of a family which managed the dairy farm, and especially in one who was in contact with the cows of this supply.

5. One apparently healthy cow in the herd was found to be excreting haemolytic streptococci which gave the reactions-of Lancefield's Group A and Griffith's Type 3 from one quarter of the udder. Three weeks after exclusion from the herd, clinical signs appeared of induration in this quarter only of the cow's udder.

6. Comparison of the tables given for this epidemic with previous experience in the burgh and the whole area, and comparison of primary and secondary cases in this epidemic, shows:

(a) that in the milk-borne epidemic the usual selective incidence of nonmilk-borne scarlet fever in children, especially females, is replaced by a more widespread incidence in both sexes and all age grôps of the population;

(b) that the proportion of houses with multiple $(1,2,3,4, \ldots)$ cases is different, if these cases are primary, from the proportion if the cases are secondary.

\section{REFERENCES}

Dovglas, R. (1935). Special Report to the County Council on Scarlet Fever in Moray and Nairn.

Hill, A. B. \& Mitra, K. (1936). Lancet, 2, 589.

Picken, R. M. F. (1936). Brit. med. J. 1, 1291.

Scotт, H. H. (1934). Some Notable Epidemics, p. 136.

Sleigh, J. C. (1936). Med. Officer, 55, 25.

(MS. received for.publication 23. x. 41.-Ed.) 